\title{
FLORISTIC RELATIONSHIPS OF THE RAINFOREST FLORA OF NEW GUINEA
}

\author{
T. G. HARTLEY
}

(Accepted for publication 16.9.1983)

\begin{abstract}
Hartley, T. G. (Australian National Herbarium, CSIRO Division of Plant Industry, P.O. Box 1600, Canberra, Australia 2601) 1986. Floristic relationships of the rainforest flora of New Guinea. Telopea 2(6): 619-630 - A survey is made of the overall geographic distributions of 716 genera of New Guinea rainforest seed plants and a rather detailed analysis is made of the geographic distributions and apparent New Guinea origins of the genera of non-aurantioid Rutaceae that occur in New Guinea. Of the 716 genera, $140(19.6 \%)$ have cosmopolitan, pantropical or tropical trans-Pacific distributions; $24(3.3 \%)$ have mainly temperate distributions (these are about equally divided between north temperate and south temperate genera); $413(57.7 \%)$ appear to centre, in their distributions, on tropical regions to the north and west of New Guinea; and the remaining $139(19.4 \%)$ appear to centre on Australasia (54 of these are restricted, or nearly restricted to New Guinea; 11 appear to centre on New Guinea and range into the Pacific; and the remaining 74 occur in Australasia to the south of New Guinea). Besides the 65 genera that appear to have originated in New Guinea, it appears that the New Guinea rainforest flora is composed almost entirely of genera that have arrived from western Malesia or Australia. Of the 11 genera of non-aurantioid Rutaceae that occur in New Guinea, eight appear to have arrived from Australia, two from western Malesia, and one from western Malesia and Australia.
\end{abstract}

\section{INTRODUCTION}

The island of New Guinea is of particular interest phytogeographically because it has probably been the main site of interchange between the floras of South-East Asia and Australia. Judging from recent palaeogeographic studies (Doutch 1972, Crook \& Belbin 1978, Coleman 1980), it has probably been accessible to Australian plants throughout most of the Tertiary, whereas it was probably first colonized by South-East Asian plants in the Miocene.

The southern part of New Guinea, as the northern margin of the Australian plate, is believed to have had a long history of land connection with northern Australia during the early Mesozoic. From about the mid-Jurassic to the mid-Cretaceous, however, practically all of the area was covered by sea. Regression of the sea is thought to have begun in the mid-Cretaceous and by the early Tertiary (Eocene) a broad northern Australian-southern New Guinean land mass was again established. This connection is believed to have remained intact until the Pleistocene, when it was severed by the Torres Strait seaway.

The northward drift of the Australian plate in the Tertiary is believed to have resulted in it colliding with the Borneo-Celebes platform of the China plate. The latter event is thought to have occurred 15 to 20 m.y. ago in the mid-Miocene and is generally accepted as the first contact between New Guinea and the Malesian archipelago (van Steenis $(1971,1979)$, however, argues for an earlier contact as well). 
Certain other events in the palaeogeographic development of the south-west Pacific region are also relevant to the historical phytogeography of New Guinea. In the late Cretaceous and early Tertiary, rifting and sea floor spreading are believed to have brought about the breakup of eastern Gondwanaland and the separation of Australia from Antarctica. As a result, the lands that are now New Zealand and New Caledonia, both of which had been part of eastern Gondwanaland, became geographically isolated by the formation of the Tasman and Coral Seas, and the formation of the Southern Ocean between Australia and Antarctica severed the more or less continuous land link that had existed between Australia and South America via Antarctica and Tierra del Fuego. New Guinea seed plant genera common to Australia and New Zealand and/or New Caledonia, or to Australia and temperate South America, thus may have been widely distributed in Gondwanaland at least as long ago as the early Tertiary.

In order to make an assessment of the floristic relationships of the New Guinea rainforest flora, I have (i) made a survey of the overall geographic distributions of a fairly inclusive number of New Guinea rainforest seed plant genera, and (ii) made a rather detailed analysis of the geographic distributions and apparent New Guinea origins of the genera of non-aurantioid Rutaceae that occur in New Guinea.

\section{SEED PLANT GENERA}

From personal experience in New Guinea (Hartley et al. 1973) and from relevant taxonomic and floristic publications, I have compiled a list of $716 \mathrm{New}$ Guinea rainforest seed plant genera. Included are genera more or less restricted to primary, ever-wet New Guinea forests ranging from sea level to over $3000 \mathrm{~m}$. Genera more or less restricted to secondary growth, monsoon forests, ocean beach scrub and swamp communities are not included. Data for geographic distributions were compiled from the phytogeographic studies of van Balgooy (1971, 1975), the dictionaries of Willis (1973) and Burbidge (1963), and from relevant taxonomic and floristic publications.

Following are descriptions of the types of distributions represented among these genera, with lists of representative genera. While most of the terms used for geographic areas are self-explanatory, the following may require definition: the Malagasy region includes Madagascar, the Mascarenes and the Seychelles; South-East Asia includes Sri Lanka, most of India, Burma, Indo-China and southern China including Taiwan; western Malesia includes the Philippines, Borneo, Malaya, Sumatra and Java; eastern Malesia includes the Celebes and Moluccas; and the Fijian region includes Fiji, Samoa and Tonga.

\section{Cosmopolitan or widespread tropical genera}

These occur in at least tropical America and the Old World tropics. Of the genera selected, $140(19.6 \%)$ have distributions of this type. The following major distribution patterns occur among these:

1a. Present in at least tropical America, Indo-Malesia and tropical Africa (113 genera). All of these occur in western Malesia; 79 occur in the Fijian region; and 102 occur in Australia. Of those occurring in Australia, 73 also occur in New Caledonia (18 of which are also recorded from New Zealand), and 63 of these are further present in the Fijian region. 
Among these genera are Celtis (Ulm.), Beilschmiedia (Laur.), Mucuna (Fab.), Dichapetalum (Dich.), Croton (Euph.), Spondias (Anacard.), Ilex (Aquif.), Salacia (Celast.), Gouania (Rham.), Tetracera (Dill.), Ternstroemia (Theac.), Calophyllum (Gutt.), Rinorea (Viol.), Casearia (Flac.), Terminalia (Combret.), Schefflera (Aral.), Myrsine (Myrs.), Manilkara (Sapot.), Diospyros (Eben.), Strychnos (Log.), Vitex (Verb.) and Ixora (Rub.).

1b. Present in at least tropical America and Malesia; absent from mainland Africa (27 genera). Two of these, Spathiphyllum (Arac.) and Heliconia (Musac.), terminate their western distributions in eastern Malesia; 24 occur in western Malesia; 10 occur in the Fijian region; and 13 occur in Australia. Of those occuring in Australia, seven also occur in New Caledonia (two of which are also known from New Zealand), and six of these are further present in the Fijian region.

Among these genera are Engelhardia (Jugl.), Aphananthe (Ulm.), Litsea (Laur.), Picrasma (Simaroub.), Perrottetia (Celast.), Turpinia (Staphyl.), Citronella (Icac.), Sloanea (Elaeo.), Saurauia (Actinid.), Passiflora (Passif.), Planchonella (Sapot.) and Symplocus (Symploc.).

\section{North temperate genera}

These are mostly widespread in the northern hemisphere and extend from temperate Asia into Malesia via high mountains. Of the genera selected, 11 $(1.5 \%)$ have distributions of this type. Six of these, Meliosma (Sab.), Gordonia (Theac.), Aralia (Aral.), Clethra (Cleth.), Trigonotis (Borag.) and Ellisiophyllum (Scroph.), terminate their distributions in New Guinea; four, Euonymus (Celast.), Elaeagnus (Elaeag.), Rhododendron (Eric.) and Sambucus (Caprif.), range south into Australia; and one, Vaccinium (Eric.), ranges west into the Pacific via the Solomons, New Caledonia and the Fijian region.

\section{South temperate amphipacific genera}

These occur at least in temperate (or subtropical) regions of South America and in Australasia outside New Guinea. Of the genera selected, $13(1.8 \%)$ have distributions of this type. All of these occur in Australia and all but three, Gevuina (Prot.), Oreocallis (Prot.) and Drimys (Winter.), are further present in Australasia, in New Zealand and/or New Caledonia (Gevuina occurs in Fiji, however). Six of the genera, Araucaria (Arauc.), Libertia (Irid.), Nothofagus (Fag.), Gevuina, Oreocallis and Muehlenbeckia (Polygonac.), more or less terminate their distributions in New Guinea, and the remaining seven, Uncinia (Cyper.), Dianella (Liliac.), Drimys, Caldcluvia (Cunon.), Weinmannia (Cunon.), Gunnera (Halorag.) and Nertera (Rub.), range at least into western Malesia or South-East Asia (Weinmannia also occurs in Madagascar, and Gunnera occurs in Madagascar and mainland Africa).

\section{African and/or Indo-Malesian genera}

These apparently centre on tropical regions to the north and west of New Guinea, and are absent from the New World. Of the genera selected, 413 $(57.7 \%)$ have distributions of this type. The following distribution patterns occur among these:

4a. Present in at least mainland Africa (and often the Malagasy region), South-East Asia (with rare exceptions) and western Malesia (89 genera). Nineteen of these more or less terminate their distributions in New Guinea; 45 occur in the Fijian region; and 66 reach Australia. Of those that reach Australia, 
41 also occur in New Caledonia (three of which are also known from New Zealand), and 36 of these are further present in the Fijian region.

Among the genera more or less terminating their distributions in New Guinea are Aglaonema (Arac.), Phrynium (Marant.), Friesodielsia (Annon.), Santiria (Burs.), Reissantha (Celast.), Glenniea (Sapin.), Pterygota (Sterc.), Gastonia (Aral.), Toxocarpus (Asclep.) and Urophyllum (Rub.).

Among the genera reaching Australia are Flagellaria (Flag.), Antiaris (Mor.), Balanophora. (Balanoph.), Stephania (Menis.), Pittosporum (Pitt.), Macaranga (Euph.), Pleurostylia (Celast.), Ganophyllum (Sapin.), Leea (Vit.), Firmiana (Sterc.), Brackenridgea (Och.), Garcinia (Gutt.), Alangium (Alang.), Syzygium (Myrt.), Memecylon (Melast.), Polyscias (Aral.), Maesa (Myrs.), Olea (Oleac.), Alstonia (Apoc.), Gmelina (Verb.) and Pavetta (Rub.).

4b. Present in at least the Malagasy region, South-East Asia (with rare exceptions), and western Malesia; absent from mainland Africa (27 genera), Only one of these, Gluta (Anacard.), terminates its distribution in New Guinea; 21 occur in the Fijian region; and 22 reach Australia. Of those that reach Australia, 15 also occur in New Caledonia (three of which are also known from New Zealand), and 14 of these are further present in the Fijian region.

Among the genera reaching Australia are Pothos (Arac.), Galeola (Orch.), Polyalthia (Annon.), Strongylodon (Fab.), Claoxylon (Euph.), Elaeocarpus (Elaeo.), Dillenia (Dill.), Carallia (Rhiz.), Geniostoma (Log.), Alyxia (Apoc.) and Timonius (Rub.).

4c. Present in at least South-East Asia and (with rare exceptions) western Malesia; absent from Africa and the Malagasy region (211 genera). Two hundred and seven of these occur in western Malesia; 85 more or less terminate their distributions in New Guinea; 65 occur in the Fijian region; and 106 reach Australia. Of those that reach Australia, 40 also occur in New Caledonia (six of which are also known from New Zealand), and 32 of these are further present in the Fijian region.

Among the genera more or less terminating their ranges in New Guinea are Korthalsia (Palm.), Chloranthus (Chlor.), Castanopsis (Fag.), Poikilospermum (Urt.), Macrosolen (Lor.), Sycopsis (Hamm.), Scleropyrum (Sant.), Parabaena (Menis.), Phaeanthus (Annon.), Gymnacranthera (Myrist.), Actinodaphne (Laur.), Aphanamixis (Meliac.), Blumeodendron (Euph.), Galearia (Euph./ Pandac.), Daphniphyllum (Euph./Daph.), Mangifera (Anacard.), Bhesa (Celast.), Platea (Icac.), Sabia (Sab.), Anisoptera (Dipt.), Aquilaria (Thym.), Duabanga (Sonn.), Mastixia (Corn.), Micrechites (Apoc.), Aeschynanthes (Ges.) and Calophanoides (Acanth.).

Among the genera reaching Australia are Freycinetia (Pandan.), Licuala (Palm.), Alpinia (Zing.), Malaisia (Mor.), Cansjera (Opil.), Hypserpa (Menis.), Cananga (Annon.), Myristica (Myrist.), Endiandra (Laur.), Maniltoa (Fab.), Glycosmis (Rut.), Garuga (Burs.), Dysoxylum (Meliac.), Xanthophyllum (Polygal.), Bischofia (Euph.), Semecarpus (Anacard.), Harpullia (Sapin.), Ryparosa (Flac.), Tetrameles (Datis.), Phaleria (Thym.), Planchonia (Barr.), Decaspermum (Myrt.), Agapetes (Eric.), Ligustrum (Oleac.), Fagraea (Log.), Parsonsia (Apoc.), Erycibe (Conv.) and Anthocephalus (Rub.).

4d. Present in at least western Malesia; absent from Africa, the Malagasy region, and South-East Asia (86 genera). Thirty-nine of these more or less 
terminate their distributions in New Guinea; 23 occur in the Fijian region; and 28 reach Australia. Of those that reach Australia, 10 also occur in New Caledonia (three of which are also known from New Zealand), and eight of these are further present in the Fijian region.

Among the genera more or less terminating their distributions in New Guinea are Cyrtostachys (Palm.), Hylophila (Orch.), Prainea (Mor.), Lepeostegeres (Lor.), Cladomyza (Sant.), Archangelisia (Menis.), Elmerrillia (Mag.), Mitrella (Annon.), Syndyophyllum (Euph.), Koordersiodendron (Anacard.), Lophopyxis (Loph.), Schuurmansia (Och.), Pangium (Flac.), Octomeles (Datis.), Gynotroches (Rhiz.), Beccarianthus (Melast.), Harmsiopanax (Aral.), Diplocosia (Eric.), Lepiniopsis (Apoc.), Petraeovitex (Verb.) and Dichrotrichum (Ges.).

Among the genera reaching Australia are Streblus (Mor.), Dendrocnide (Urt.), Amyema (Lor.), Vavaea (Meliac.), Ryssopterys (Malpig.), Codiaeum (Euph.) and Elattostachys (Sapin.).

\section{Australasian genera}

These are restricted to, or otherwise appear to centre on, the Australasian region. Of the genera selected, $139(19.4 \%)$ have distributions of this type. The following distribution patterns occur among these:

5a. Restricted to New Guinea (including the Bismarck Archipelago) (38 genera). Among these are Papuacedrus (Cupress.), Brassiophoenix (Palm.), Distrianthes (Lor.), Kairoa (Monim.), Annesijoa (Euph.), Brassiantha (Celast.), Sericolea (Elaeo.), Papuechites (Apoc.), Lamiodendron (Bignon.), Oxychlamys (Ges.) and Versteegia (Rub.).

5b. Nearly restricted to New Guinea (also occurring in the Moluccas and/or the Solomons) (16 genera). Among these are Rhopaloblaste (Palm.), Sogerianthe (Lor.), Polyporandra (Icac.), Hollrungia (Passif.) and Eucalyptopsis (Myrt.):

5c. Centring on New Guinea and ranging east into the Pacific to at least as far as the Fijian region; absent from Australasia outside Papuasia (11 genera). Of the 11 genera, 10 also occur in eastern Malesia. Among these are Drymophloeus (Palm.), Spiranthemum (Cunon.), Rejoua (Apoc.), Airosperma (Rub.) and Mastixiodendron (Rub.).

5d. Present in Australia but absent from New Caledonia and New Zealand (37 genera). Of the 37 genera, 17 also occur in eastern Malesia, two in western Malesia, and two in the Fijian region. Among these are Hydriastele (Palm.), Legnephora (Menis.), Galbulimima (Himentand.), Eupomatia (Eupomat.), Dryadodaphne (Monim./Athrosperm.), Piptocalyx (Monim./Trimen.), Palmeria (Monim.), Hymenosporum (Pitt.), Ceratopetalum (Cunon.), Choriceras (Euph.), Tochima (Sapin.), Aceratium (Elaeo.), Mackinlaya (Aral.) and Neosepicaea (Bignon.).

5e. Present in Australia and New Caledonia but absent from New Zealand (21 genera). Of the 21 genera, 11 also occur in eastern Malesia, six in western Malesia, and three in the Fijian region. Among these are Grevillea (Prot.), Amylotheca (Lor.), Bubbia (Winter.), Polyosma (Sax.), Acsmithia (Cunon.), Anthocarapa (Meliac.), Fontainea (Euph.), Euroschinus (Anacard.), Sphenostemon (Aquif./Sphenostem.), Durandea (Linac.), Xanthomyrtus (Myrt.) and Tapeinosperma (Myrs.). 
5f. Present in Australia, New Caledonia, and New Zealand (four genera). Of the four genera, three also occur in eastern Malesia, three in western Malesia, and two in the Fijian region. These are Agathis (Arauc.), Corynocarpus (Corynoc.), Quintinia (Sax.) and Metrosideros (Myrt.).

5g. Present in Australia and New Zealand but absent from New Caledonia (four genera). Of the four genera, three also occur in eastern Malesia, one in western Malesia, and one in the Fijian region. These are Phyllocladus (Podocarp.), Tecomanthe (Bignon.), Coprosma (Rub.) and Olearia (Comp).

5h. Present in New Caledonia but absent from Australia and New Zealand (six genera). Of the six genera, two also occur in eastern Malesia and two in the Fijian region. These are Trimenia (Monim./Trimen.), Hunga (Rosac./ Chrysobal.), Alphandia (Euph.), Dubouzetia (Elaeo.), Agatea (Viol.) and Periomphale (Caprif.).

5i. Present in New Zealand but absent from Australia and New Caledonia. One genus, Carpodetus (Sax.).

\section{SUMMARY AND DISCUSSION}

Of 716 New Guinea rainforest genera, $140(19.6 \%)$ have cosmopolitan, pantropical, or tropical trans-Pacific distributions; $24(3.3 \%)$ have mainly temperate distributions (these are about equally divided between north temperate and south temperate genera); $413(57.7 \%)$ appear to centre, in their distributions, on tropical regions to the north and west of New Guinea; and the remaining $139(19.4 \%)$ appear to centre on Australasia (54 of these are restricted, or nearly restricted, to New Guinea; 11 appear to centre on New Guinea and range into the Pacific; and the remaining 74 occur in Australasia to the south of New Guinea).

With regard to the regional occurrence of these genera, 571 (about 80\%) occur in western Malesia, 269 (about 37\%) in the Fijian region, and 447 (about $62 \%$ ) in other parts of Australasia (421 of these occur in Australia). Of the 421 genera that occur in Australia, 226 also occur in New Caledonia and/or New Zealand.

Besides the 65 genera that appear to have originated in New Guinea (distribution types $5 \mathrm{a}-\mathrm{c}$ ), it appears that the New Guinea rainforest flora is cumposed almost entirely of genera that have arrived from either western Malesia or Australia. Although over a third of the genera are shared with the Fijian region, it is apparent, as van Balgooy (1971) has shown, that the flora of that region is basically an attenuated Malesian one. Genera with trans-Pacific tropical distributions (type lb) may have arrived from the east, but there seems to be little evidence that more than a very few did; they are practically all widely distributed in Indo-Malesia (two, Spathiphyllum (Arac.) and Heliconia (Musac.), terminate their western distributions in eastern Malesia), and the majority are absent from the Fijian region.

Since the number of genera shared with western Malesia is considerably higher than that shared with Australia, there is little doubt that New Guinea has received more of its rainforest genera from areas to the north and west of the island than from the south. Although New Guinea must have initially been occupied by Australian plants, it appears that it was subsequently more or less over-run by South-East Asian plants, perhaps because the original Australian occupants were temperate or subtropical in origin and thus less favoured by the 
tropical conditions that existed on the island by the time contact was made with the Malesian archipelago.

As I have noted previously (Hartley et al. 1973), genera that have apparently arrived from the south tend to be most prevalent in New Guinea in the montane forests (above about $900 \mathrm{~m}$ ). Many of these genera appear to be restricted to montane forests in New Guinea, for example Phyllocladus (Podocarp.), Nothofagus (Fag.), Drimys (Winter.), Dryadodaphne (Monim./ Athrosperm.), Piptocalyx (Monim./Trimen.), Quintinia (Sax.), Acsmithia (Cunon.), Pullea (Cunon.), Sphenostemon (Aquif./Sphenostem.), Xanthomyrtus (Myrt.) and Gunnera (Halorag.), but others range from lowland or foothill to montane forests, for example Grevillea (Prot.), Stenocarpus (Prot.), Galbulimima (Himentand.), Levieria (Monim.), Steganthera (Monim.), Polyosma (Sax.), Ceratopetalum (Cunon.), Weinmannia (Cunon.) and Flindersia (Rut.). A few southern genera, for example Oreocallis (Prot.) and Eupomatia (Eupomat.), seem to be restricted in New Guinea to forests below $900 \mathrm{~m}$. While it is true that southern genera are most commonly encountered in the mountains, the lowlands being dominated by northern and western genera, I doubt if the mountain forests are dominated by southern genera. In an analysis of the New Guinea flora, van Balgooy (1976) found that if all genera are taken into account, the mountains as well as the lowlands are dominated by genera that have apparently arrived in New Guinea from the north and west.

Schodde \& Calaby (1972) have suggested that the tree genera of New Guinea rainforests above $1500 \mathrm{~m}$ are predominantly, if not exclusively, of southern affinity. This may be true if the analysis is restricted to genera confined to this habitat, but if genera with wide altidudinal ranges in New Guinea are included, it is evident that many of the subcanopy and canopy trees of this habitat belong to genera that have probably arrived in New Guinea from the north or west, for example Polyalthia (Annon.), Myristica (Myrist.), Prunus (Rosac.), Endospermum (Euph.), Macaranga (Euph.), Ilex (Aquif.), Lophopetalum (Celast.), Turpinia (Staphyl.), Platea (Icac.), Ganophyllum (Sapin.) Firmiana (Sterc.), Dillenia (Dill.), Adinandra (Theac.), Ternstroemia (Theac.), Calophyllum (Gutt.), Garcinia (Gutt.), Gynotroches (Rhiz.), Arthrophyllum (Aral.), Fagraea (Log.), Alstonia (Apoc.) and Neonauclea (Rub.).

Many of the New Guinea genera were probably widespread in Gondwanaland in the late Cretaceous and/or early Tertiary, the most likely ones being those that occur in both temperate South America and Australia or are common to Australia and New Caledonia and/or New Zealand. Many of the genera with the latter type of distribution have apparently arrived in Australasia more recently, however. Of the 226 genera common to Australia and New Caledonia and/or New Zealand, 168 (over $70 \%$ ) are also present in the Fijian region. Since the flora of the Fijian region is predominantly Malesian, it would seem most likely that most of these 168 genera have arrived in Australasia since the mid-Miocene contact between New Guinea and the Malesian archipelago. It should be noted, however, that a few apparently Gondwanean genera occur in the Fijian region, some examples among the New Guinea genera being Agathis (Arauc.), Gevuina (Prot.), Acsmithia (Cunon.), Pullea (Cunon.) and Weinmannia (Cunon.). Some other apparently Gondwanean New Guinea genera are Nothofagus (Fag.), Grevillea (Prot.), Bubbia (Winter.), Beilschmiedia (Laur.), Polyosma (Sax.), Caldcluvia (Cunon.), Flindersia (Rut.), Euroschinus (Anacard.), Corynocarpus (Corynoc.), Sphenostemon (Aquif./Sphenostem.), Citronella (Icac.), Sloanea (Elaeo.) and Rhodamnia (Myrt.). 


\section{NON-AURANTIOID RUTACEAE}

The non-aurantioid Rutaceae, all of which are rainforest plants in New Guinea, are represented in the Indo-Malesian-Australasian region by 24 rainforest genera. Thirteen of these do not occur in New Guinea: Boenninghausenia Reichb., Skimmia Thunb. and Tetradium Lour. (including Euodia sections Tetradium (Lour.) Engl., Evodioceras Dode and Subtrigonospermum Huang) are widespread in South-East and east Asia and terminate their distributions in Malesia to the west or north of New Guinea; Toddalia Juss. has an African-Indo-Malesian distribution that terminates in western Malesia; Acradenia Kipp. (including Luerssenidendron Domin), Bosistoa F. Muell., ex Benth. (including Pagetia F. Muell.), Bouchardatia Baill., Brombya F. Muell. and Pentaceras Hook. f. are endemic to eastern Australia; Comptonella Bak. f., Dutaillyea Baill. and Zieridium Baill. are endemic to New Caledonia; and Sarcomelicope Engl. (including Bauerella Borzi) ranges from eastern Australia east to New Caledonia and Fiji.

The eleven genera that occur in New Guinea are listed below with notes on their distributions and apparent origins in New Guinea.

\section{Acronychia J. R. \& G. Forst. (including Pleiococca F. Muell.)}

Acronychia, which was recently revised (Hartley 1974), ranges from India east to south-west China and Taiwan, south-east throughout Malesia to the Solomons, New Caledonia, and Lord Howe Island, and south in eastern Australia from Cape York Peninsula to eastern Victoria. Despite this rather wide distribution the genus is almost entirely eastern Australian and New Guinean, 17 of the 46 known species (four have not yet been published; two from New Guinea and two from Australia) being endemic to the former area and 26 to the latter. Of the remaining species, one is common to eastern Australia, Lord Howe Island and New Caledonia, one is distributed from mainland Asia throughout Malesia to New Guinea, and one ranges from Java east to the Solomons. As is shown in the revision, the most primitive species of the genus occur in Australia and it is thus probable that the genus initially colonized New Guinea from Australia. It is noteworthy that the two species that occur in western Malesia are among the most highly derived.

Euodia J. R. \& G. Forst.

Euodia has traditionally been considered to be a large genus of about 200 species that ranges throughout the Madagascar-Indo-Pacific-eastern Asian region. I regard it (unpubl.) as a small genus of about six species (most of the 200 species are more correctly placed in either Melicope or Tetradium). Euodia has highly and rather pleasantly aromatic leaves and is widely cultivated throughout Melanesia to Samoa; it is probably indigenous only in New Guinea, the Solomons and north-east Queensland. It is apparently most closely related to the genus Brombya, which is endemic to north-east Queensland, and seems likely to have been derived from it (Brombya has eight stamens, Euodia has four or very rarely eight). It is thus probable that Euodia arrived in New Guinea from Australia.

\section{Evodiella van der Linden}

Evodiella consists of five or perhaps six species, one common to north-east Queensland (from about Cooktown south to Rockingham Bay, including the Atherton Tableland) and New Guinea, and four or five endemic to New Guinea. The phylogenetic relationships of the genus and the species are not clear, but the distribution of the genus would appear to indicate that it is of Australian origin. 
Flindersia R. Br.

Flindersia is known to occur naturally in the Moluccas (Ceram and Tanimbar Islands), New Guinea, New Caledonia and eastern Australia from Cape York Peninsula south to south-central New South Wales. It consists of 17 species, one endemic to New Guinea and the Moluccas, one endemic to New Caledonia, 11 endemic to Australia, and four common to Australia and New Guinea. In a recent revision (Hartley 1969) and subsequent study (Hartley \& Hyland 1975), it has been shown that three of the four most primitive species occur in Australia - F. brassii Hartley \& Hyland and F. brayleyana F. Muell. are endemic to north-east Queensland, $F$. laevicarpa White \& Francis is common to north-east Queensland and New Guinea (the Queensland and New Guinean plants are recognized as different varieties), and $F$. fournieri Panch. \& Sebert is endemic to New Caledonia - and that the centre of morphologic diversity of the genus is clearly in Australia. It is thus most likely that the New Guinean taxa (and the New Caledonian species) are of Australian ancestry.

\section{Geijera Schott}

Geijera apparently consists of about six species, one common to New Guinea and Australia (and possibly New Caledonia), two or three endemic to New Caledonia, and two or three endemic to Australia. The single New Guinean species, $G$. salicifolia Schott, is of widespread occurrence in rainforest areas of Queensland and New South Wales (it also spreads inland in drier habitats), and in view of this, and the overall distribution of the genus, it would appear to have arrived in New Guinea from Australia.

\section{Halfordia F. Muell.}

Halfordia apparently consists of three species, one nearly endemic to New Guinea (also occurring in the Moluccas and the Solomons), one endemic to rainforests of north-east Queensland, and one occurring in south-east Queensland-north-east New South Wales rainforests, New Caledonia and the New Hebrides. Morphologically, these species are all very similar, but the two species that occur in Australia are clearly more closely related to one another than either is to the New Guinean species. In view of the essentially Australian-New Caledonian-New Guinean distribution of the genus, and the obviously relictual distribution of the two species in Australia, it seems most likely that the New Guinean species is of Australian ancestry.

\section{Lunasia Blanco}

Lunasia, which is a remarkably distinct genus without any apparent close relatives, is monotypic and ranges from the Philippines and Borneo south to Java and east to New Guinea and the tip of Cape York Peninsula. As is evident in a recent revision (Hartley 1967), the genus is far more diverse morphologically in western Malesia (especially the Philippines) than in New Guinea. Since New Guinea would seem to offer nearly as much scope for morphological diversification as western Malesia, this would seem to indicate that the genus has been in the latter region for a longer period of time.

\section{Medicosma Hook. f. (including Coombea van Royen)}

In my recent studies (unpubl.) it has become evident that the genus Medicosma, previously considered to be monotypic and endemic to eastern Australia, consists of about 15 species. About five of these are endemic to eastern Australia, eight or so are endemic to New Caledonia, and one, which is the type and only species of the recently described genus Coombea, is endemic 
to southern New Guinea. The morphological diversity of the genus is considerable in both Australia and New Caledonia, but it appears that the most primitive species occurs in Australia. The New Guinean species, which is known only from the Merauke District, is quite clearly of Australian ancestry.

\section{Melicope J. R. \& G. Forst.}

The genus Melicope, as I interpret it (unpubl.), consists of perhaps 150 species and is distributed from Madagascar to India and southern China, throughout Malesia, Micronesia, Melanesia and Polynesia to the Society Islands, and south to south-eastern Australia and New Zealand. Probably about a third of the species occur in New Guinea. Although there are only about 10 species in Australia, about eight in New Caledonia, and two in New Zealand, these appear to include just about all of the basic morphological variability found in the genus. Also, the genera that appear to be the closest possible ancestral relatives of Melicope are all restricted to Australia or otherwise appear to be Australian in origin, these being Acradenia, Bosistoa, Bouchardatia, Brombya, Euodia and Medicosma. It thus seems most likely that Melicope is of Australian origin.

\section{Tetractomia Hook. f.}

Tetractomia, another remarkably distinct genus without any apparent close relatives, is entirely Malesian in distribution, ranging from the Malay Peninsula and Sumatra east to the Solomon Islands. It consists of one widespread polymorphic species and five local species, one each from southern Malaya, the Celebes and Guadalcanal, and two from the Vogelkop Peninsula of New Guinea. As I have shown in a revision of the genus (Hartley 1979), the widespread species and the one from southern Malaya appear to be the most primitive, and the one from Guadalcanal appears to be the most highly derived. Since both of the primitive species occur in western Malesia, and the widespread one of the two shows the greatest amount of morphological diversity in that region, it would appear that the genus initially colonized New Guinea from the north or west.

\section{Zanthoxylum L. (including Fagara L.)}

A genus of about 200 species, Zanthoxylum is mainly pantropical in distribution. There are, in addition, several temperate-latitude species in eastern Asia, and one in North America. As I have shown in a revision and subsequent studies of the Malesian species of the genus (Hartley 1966, 1970, 1975), 20 species occur in Malesia, of which nine occur in New Guinea (six are restricted, or nearly restricted, to New Guinea). In the Indo-Pacific region the greatest basic morphological diversity and the largest number of apparently primitive species occur in South-East Asia-western Malesia. On the basis of species relationships there is evidence, however, that the genus colonized New Guinea from both Australia and western Malesia. The Australian connection is probably the older one, especially in view of the close relationship between the endemic New Guinean montane species Z. conspersipunctatum Merr. \& Perry and two geographically disjunct and apparently vicarious eastern Australian rainforest species, $Z$. venificum F. M. Bailey of north-east Queensland, and $Z$. brachyacanthum F. Muell., which ranges from the Eungella Range in east-central Queensland south to north-eastern New South Wales. 


\section{SUMMARY}

Of the 11 genera of non-aurantioid Rutaceae that occur in New Guinea, eight (Acronychia, Euodia, Evodiella, Flindersia, Geijera, Halfordia, Medicosma and Melicope) appear to have arrived from Australia, two (Lunasia and Tetractomia) appear to have arrived from western Malesia, and one (Zanthoxylum) appears to have arrived from both western Malesia and Australia, but probably first from Australia.

\section{REFERENCES}

Balgooy, M. M. J. van (1971). Plant geography of the Pacific, as based on the distribution of phanerogam genera. Blumea, Suppl. 6: 1-222.

Balgooy, M. M. J. van (1975). 'Pacific Plant Areas' (Rijksherbarium: Leiden) vol. III.

Balgooy, M. M. J. van (1976). Phytogeography. In Paijmans, K. (Ed.), 'New Guinea Vegetation' (Australian National Univ. Press: Canberra) pp.1-22.

Burbidge, N. T. (1963). 'Dictionary of Australian Plant Genera' (Angus \& Robertson: Sydney).

Coleman, P. J. (1980). Plate tectonics background to the biogeographic development in the southwest Pacific over the last 100 million years. Palaeogeogr. Palaeoclimatol. Palaeoecol. 31: 105-121.

Crook, K. A. W. \& Belbin, L. (1978). The southwest Pacific area during the last 90 million years. J. Geol. Soc. Austral. 25: 23-40.

Doutch, H. F. (1972). The paleogeography of northern Australia and New Guinea and its relevance to the Torres Strait area. In Walker, D. (Ed.), 'Bridge and Barrier: the Natural and Cultural History of Torres Strait' (Australian National Univ.: Canberra) pp.1-10.

Hartley, T. G. (1966). A revision of the Malesian species of Zanthoxylum (Rutaceae). J. Arnold Arbor. 47: 171-221.

Hartley, T. G. (1967). A revision of the genus Lunasia (Rutaceae). J. Arnold Arbor. 48: 460-475.

Hartley, T. G. (1969). A revision of the genus Flindersia (Rutaceae). J. Arnold Arbor. 50: 481- 526.

Hartley, T. G. (1970). Additional notes on the Malesian species of Zanthoxylum (Rutaceae). J. Arnold Arbor. 51: 423-426.

Hartley, T. G. (1974). A revision of the genus Acronychia (Rutaceae). J. Arnold Arbor. 55: 469-567.

Hartley, T. G. (1975). A new species of Zanthoxylum (Rutaceae) from New Guinea. J. Arnold Arbor. 56: 369-373.

Hartley, T. G. (1979). A revision of the genus Tetractomia (Rutaceae). J. Arnold Arbor. 60: 127-153.

Hartley, T. G., Dunstone, E. A., Fitzgerald, J. S., Johns, S. R. \& Lamberton, J. A. (1973). A survey of New Guinea plants for alkaloids. Lloydia 36: 217-319.

Hartley, T. G. \& Hyland, B. P. M. (1975). Additional notes on the genus Flindersia (Rutaceae). J. Arnold Arbor. 56: 243-247.

Schodde, R. \& Calaby, J. H. (1972). The biogeography of the Australo-Papuan bird and mammal faunas in relation to Torres Strait. In Walker, D. (Ed.), 'Bridge and Barrier: the Natural and Cultural History of Torres Strait' (Australian National Univ.: Canberra) pp. 257-300. 
Steenis, C. G. G. J. van (1971). Nothofagus, key genus of plant geography, in time and space, living and fossil, ecology and phylogeny. Blumea 19: $65-98$.

Steenis, C. G. G. J. van (1979). Plant-geography of east Malesia. J. Linn. Soc., Bot. 79: 97-178.

Willis, J. C. (1973). 'A Dictionary of the Flowering Plants and Ferns' (revised by H. K. Airy Shaw) (Cambridge Univ. Press: Cambridge) edn 8. 